УДК: 811.161.2:378.147-054.6

DOI: 10.26697/ijes.2019.2.23

\section{Комунікативний напрям навчання української мови як іноземної на початковому етапі}

Старший викладач Токусва Н. В. ${ }^{1}, \quad$ старший викладач Мікос I. М. ${ }^{1}$, старший викладач Петренко Л. Ф. ${ }^{1}$

${ }^{1}$ Полтавська державна аграрна академія, Украӥна

\begin{abstract}
Резюме
Вступ:

Підготовка іноземних спеціалістів в українських закладах вищої освіти має багаторічний досвід. Форми, методи і принципи навчання іноземців в Україні були предметом багатьох наукових досліджень, починаючи 3 середини XX століття. Серед основних принципів навчання було визначено комунікативність, урахування рідної мови іноземця, взаємодія системного вивчення української мови 3 комунікативним напрямом навчання.

Метою дослідження $є$ аналіз поняття мовне спілкування в навчальному процесі, його структура, види й форми, що необхідно враховувати при реалізації комунікативної направленості навчання.
\end{abstract}

\section{Результати:}

Комунікативність як певний інтегральний підхід, через призму якого розглядаються, висвітлюються й оцінюються традиційні і нові лінгводидактичні і методичні принципи, положення, рішення, окреслює орієнтацію змісту навчання на спілкування, а отже, визначається не граматикою, а природою самого спілкування, функціонуванням системи сучасної української мови, метою i комунікативними потребами іноземців в реальній дійсності. Комунікативність характеризує усі сторони навчального процесу, визначає засоби використання законів засвоєння матеріалу, окреслює зміст, методи й організацію навчання, презентує систему мови в мовних актах для виконання певних комунікативних завдань.

На початковому (підготовчому) етапі вивчення іноземцями української мови достатній рівень оволодіння мовою може бути досягнутий лише за умови відпрацювання мовних явищ у завданнях чи вправах, що відтворюють або імітують реальну комунікацію. Для фонетичної розминки, навчання діалогічного мовлення, проведення рольових комунікативних ігор можуть бути запропоновані теми: "Привітання”, “Знайомство”, “Запрошення”, "Прощання", "Проведення вільного часу", "У бібліотеці”, “у поліклініці”, “Покупки”, “у транспорті" тощо. Подання лексичних одиниць, граматичних структур i моделей у контексті реальної емоційної ситуації сприяє кращому запам'ятовуванню та активізації даного матеріалу у мовленні. Велике значення в успішному виконанні поставлених завдань має формування конкретного мотиву спілкування, зацікавленість у тематиці й максимальне залучення іноземців до активної творчої діяльності. У навчання необхідно також використовувати прийоми, що забезпечують реальне спілкування в навчальній аудиторії: складання діалогів i монологічних висловлювань, вирішення проблемних завдань, проведення інтерв'ю, дискусій, конференцій. Ефективність даних видів практичних занять полягає в тому, щоб комунікантів було поставлено в умови, коли вони повинні самостійно висловити свою думку, внести пропозиції, запросити інформацію, порівняти, погодитися чи спростувати твердження товаришів. Мовні форми не повинні бути заготовленими заздалегідь; вони повинні підбиратися промовцем під час семантико-граматичного структурування висловлювання. Викладач повинен уміло підтримувати й направляти мовну ініціативу іноземців, адже стимулювання непідготовленого мовлення $\epsilon$ одним із головних завдань навчання мови як іноземної, а оволодіння мовною компетенцією - кінцевою метою навчання.

\section{Висновки: \\ Взаємодія системного вивчення української мови як іноземної 3 комунікативною направленістю навчання виявляється у здійсненні навчання фонетики, лексики, морфології на синтаксичній основі, що дозволяє іноземцю на кожному етапі формування мовних навичок переходити на рівень мовленнєвих умінь, тобто творчо використовувати засоби мови, а у подальшому - перенести ці знання до умов реального спілкування.}

\begin{abstract}
Інформація про авторів:
Токуєва Наталія Володимирівна - старший викладач відділу мовної підготовки, Центр міжнародної освіти Полтавської державної аграрної академії, Полтава, Україна.

Наукові інтереси: українська мова як іноземна, методика викладання, навчання іноземців, комунікативний напрям навчання.

Мікос Ірина Миколаївна - старший викладач відділу мовної підготовки, Центр міжнародної освіти Полтавської державної аграрної академії, Полтава, Україна.

Наукові інтереси: українська мова як іноземна, методика викладання, навчання іноземців, комунікативний напрям навчання.

Петренко Людмила Федорівна - старший викладач відділу мовної підготовки, Центр міжнародної освіти Полтавської державної аграрної академії, Полтава, Україна.

Наукові інтереси: українська мова як іноземна, методика викладання, навчання іноземців, комунікативний напрям навчання.
\end{abstract}

Автор-Кореспондент:

Токуєва Наталія Володимирівна

Email Автора-Кореспондента: tokuyeva@gmail.com 